\title{
POTASSIUM SILICATE FOLIAR FERTILIZER GRADE FROM GEOTHERMAL SLUDGE AND PYROPHYLLITE
}

\author{
Srie Muljani, Bambang Wahyudi, Ketut Sumada, Suprihatin \\ University of Pembangunan Nasional "Veteran" Jawa Timur \\ Surabaya, Indonesia \\ E-Mail : eboy_tk@yahoo.com
}

\begin{abstract}
Potassium silicate fertilizer grade were successfully produced by direct fusion of silica $\left(\mathrm{SiO}_{2}\right)$ and potasium $(\mathrm{KOH}$ and $\left.\mathrm{K}_{2} \mathrm{CO}_{3}\right)$ in furnaces at temperatures up to melting point of mixture. The geothermal sludge $\left(98 \% \mathrm{SiO}_{2}\right)$ and the pyrophyllite $\left(95 \% \mathrm{SiO}_{2}\right)$ were used as silica sources. The purposes of the study was to synthesise potassium silicate fertilizer grade having solids concentrations in the range of $31-37 \% \mathrm{~K}_{2} \mathrm{O}$, and silica in the range of $48-54 \% \mathrm{SiO}_{2}$. The weight ratio of silicon dioxide/potasium solid being 1:1 to 5:1. Silica from geothermal sludge is amorphous, whereas pyrophylite is crystalline phase. The results showed that the amount of raw materials needed to get the appropriate molar ratio of potassium silicate fertilizer grade are different, as well as the fusion temperature of the furnace. Potassium silicate prepared from potassium hydroxide and geothermal sludge produced a low molar ratio (2.5: 1 to $3: 1)$. The potassium required quite small (4:1 in weight ratio), and on a fusion temperature of about $900{ }^{\circ} \mathrm{C}$. Meanwhile, the potassium silicate prepared from pyrophyllite produced a high molar ratio $\left(1.4\right.$ - 9.4) and on a fusion temperature of about $1350{ }^{\circ} \mathrm{C}$, so that potassium needed large enough to meet the required molar ratio for the fertilizer grade. The product potassium silicate solid is amorphous with a little trace of crystalline.
\end{abstract}

Keywords: geothermal sludge, pyrophyllite, fusion reaction, potassium silicate solid, fertilizer

\section{INTRODUCTION}

Potassium or sodium water glasses are generally produced on an industrial scale by melting together quartz sand and sodium/potassium carbonate in suitable furnaces at temperatures in the range of $1400^{\circ}$ to $1500^{\circ} \mathrm{C}$ with the splitting-off of carbon dioxide. This high-temperature melt process is, however, very costly both in equipment and as regards the amounts of energy required and leads moreover to not inconsiderable emissions, such as dust, nitrogen oxides, and sulfur oxides (US 5238668 A). The alkali extraction and acid precipitation method, low energy method, has also been successfully used to produce silicate solution (Muljani et al, 2014), but this method is less precise when solid silicate product is desired. The hydrothermal reaction of quartz sand with aqueous potassium hydroxide obtained potassium silicate solutions which have $\mathrm{SiO}_{2}: \mathrm{K}_{2} \mathrm{O}$ molar ratios of less than 2.75:1. However, in this case, hydrothermal reaction must go through a two-stage process: stage quartz reaction with $\mathrm{KOH}$ solution at a temperature of $300 \mathrm{C}$ and quartz reaction stage at a temperature up to melting point (over $1100{ }^{\circ} \mathrm{C}$ ).

$\mathrm{SiO}_{2}$ structural differences between amorphous and crystalline silica can lead to differences in dissolution behavior. But the physical properties of amorphous silica remains elusive in comparison to crystalline silica based on the more comprehensive quartz dissolution studies. There are also known hydrothermal processes for the production of aqueous potassium silicate solutions that are described in a number of patent applications. Gunnarsson, et al (2010) reported that the solubility of amorphous silica at 1 bar and a temperature of about $200{ }^{\circ} \mathrm{C}$ is higher than the solubility at higher temperatures. Some mixtures of silica and alkali metal silicates have somewhat lower melting temperatures, than the alkali metal carbonates used (US 2823098 A).

In this study, the use of amorphous silica and alkaline hydroxide for potassium silicate production is expected to reduce the energy while reducing air pollution, especially carbon dioxide. The mixture of alkaline hydroxide and silica may lower the melting point of the mixture. It is caused also by the solubility of amorphous silica that is lower than crystalline silica. So in the use of alkaline hydroxide the temperature should be maintained below the melt temperature of the product. In a previous study, amorphous silica purification from geothermal sludge in furnace at temperatures up to $1000{ }^{\circ} \mathrm{C}$, it is known that the impurities contained in the geothermal sludge were much reduced with the increase in temperature furnace (Muljani et al, 2011).

Potassium silicate provides an excellent source of soluble silicon for plants and also provides supplemental potassium, a plant macronutrient (Jayawardana et al, 2014). Potassium silicate is used to strengthen plant resistance to pathogens and to enhance agricultural productivity. Here a potassium silicate is proposed that can be adapted by adjusting the physico-chemical properties as requested by the formulation of fertilizers. The potassium silicate is available both in liquid and in powder form with high solubility to easily produce liquid fertilizers. The powder form can be used to make fertilizers in powder form. Yao et al, (2014) synthesized a potassium calcium silicate mixture, by fusing a mixture of $\mathrm{K}_{2} \mathrm{CO}_{3}, \mathrm{CaCO}_{3}$, and $\mathrm{SiO}_{2}$. Produced from steel-making slag, fertilizer potassium silicate compounds have received considerable attention as slowrelease potassium fertilizers beneficial for crops. 
Soluble potassium is completely water soluble and can be used as foliar fertilizers. The foliar fertilizer application of soluble $\mathrm{Si}$ has been reported to reduce powdery mildew of cucumber, mask melon, zucchini squash, grapes, and angular leaf spot of beans. The foliar spraying of Si may offer practical and viable mean of reducing plant diseases with low cost (Nolla et al, 2008). It can be synthesized by reacting potassium with silicon dioxide following this reaction

$\mathrm{SiO}_{2}+2 \mathrm{KOH} \rightarrow \mathrm{K}_{2} \mathrm{SiO}_{3}+\mathrm{H}_{2} \mathrm{O}$

$\mathrm{SiO}_{2}+\mathrm{K}_{2} \mathrm{CO}_{3} \rightarrow \mathrm{K}_{2} \mathrm{SiO}_{3}+\mathrm{CO}_{2}$

The rate of the reaction depends on the ratio of alkali metal carbonate to silicon dioxide and silica structural. Crystalline quartz will only dissolve very slowly in hot water alkaline solutions, while amorphous silicon dioxide, will be readily dissolved at room temperatures (Robert et all, 1977). Although much research on the production of potassium silicate has been done but there is no comprehensive information related to energy efficiency and economy.

This study was to investigate the effect of the raw materials and the need for potassium which can reduced the energy and raw materials. The aim of this study was to provide a process for production of potassium silicate foliar fertilizer that have potassium concentrations in the range of $31-37 \% \mathrm{~K}_{2} \mathrm{O}$, and silica in the range of $48-54 \% \mathrm{SiO}_{2}$ by the fusion reaction of silicon dioxide with potassium. The crystalline silicon dioxide (pyrophyllite) and amorphous silicon dioxide (geothermal sludge) are used in the weight ratio of silicon dioxide/potassium. The molar ratio used for a specific application depends on the desired properties and economic impact.

\section{METHODOLOGY}

\section{Potassium silicate production}

Silicon dioxide in this experiment was obtained from geothermal sludge and pyrophylite. Geothermal sludge is the solid waste from the geothermal plant located in Dieng, Central Java, Indonesia, while pyrophyllite was mined from Malang East Java, Indonesia. X-ray fluoroscence analysis showed successive silica content of about $98 \% \mathrm{SiO}_{2}$ in the geothermal sludge and about $85 \% \mathrm{SiO}_{2}$ in the pyrophyllite. To increase levels of silica in pyrophyllite it is necessary to use hydrochloric acid leaching. $0.5 \mathrm{~N} \mathrm{HCl}$ was used to remove impurities in pyrophyllite so that its purity reaches $95 \% \mathrm{SiO}_{2}$.

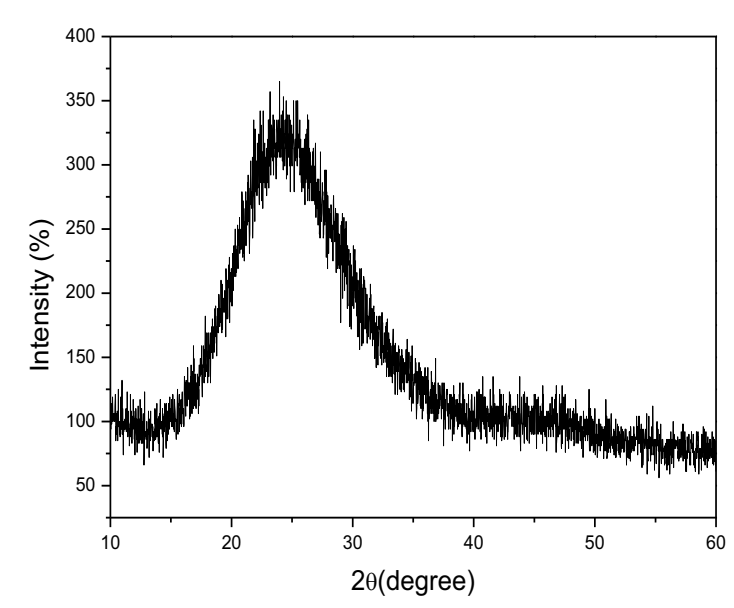

Figure 1. X-ray diffraction (XRD) patterns of silica from geothermal sludge.

X-ray diffraction (XRD) pattern have shown that the silica from geothermal sludge is amorphous (Fig. 1) and silica from pyrophyllite is crystalline (Fig. 2). The Silica obtained from the pyrophyllite sample agree very well with JCPDS data of 46-1045. However, the graphs obtained from this essay demonstrated that the pyrophyllite had a low reactivity due to the large amount of crystallinity peaks found in the charts.

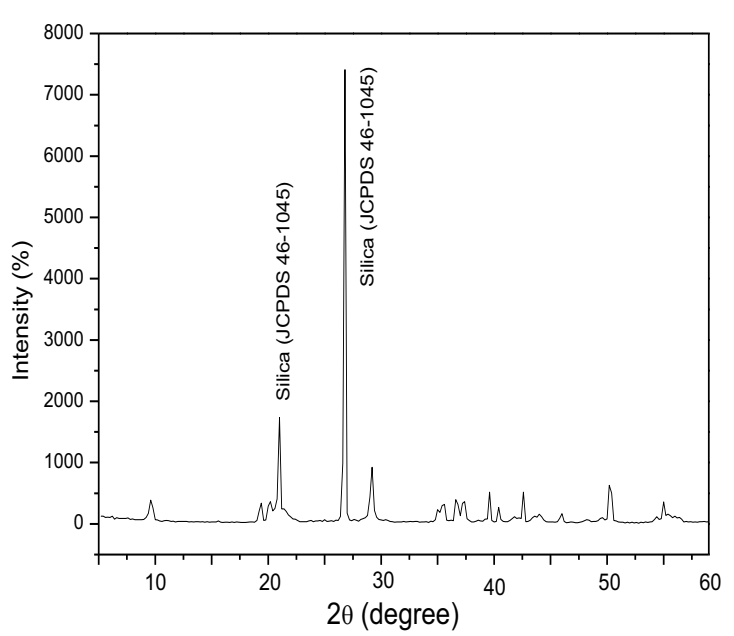

Figure 2. X-ray diffraction (XRD) patterns of silica from pyrophyllite.

Pyrophylite and geothermal sludge was crushed and sieved through 100-mesh sieves. $\mathrm{KOH}$ and $\mathrm{K}_{2} \mathrm{CO}_{3}$ is a source of potassium for the formation of potassium silicate. 
Silicon dioxide and potassium mixed by variation of the weight ratio of silica versus potassium in the range of $1: 1$ to $5: 1$. The potassium silicate obtained in different grades should have a chemical formula of $\mathrm{K}_{2} \mathrm{SiO}_{3}$. Fusion in the furnace is done such that the resulting product is only melted but still solid form. Fusion reactions over a range of temperatures below the melting point of the mixture until it reaches the melting point. The powder of silica (geothermal sludge or pyrophyllite) and potassium were mixed and then sprinkled by water until the mixture was slightly clump so not much lost powder when hot air that blows touching the mixture. The mixture was reacted in the furnace at temperature in the range of $600{ }^{\circ} \mathrm{C}$ to $1000^{\circ} \mathrm{C}$.

\section{Characterization}

X-ray diffraction (XRD) patterns of the potassium silicate were obtained using an X-ray diffractometer (X'pert, Philips). The composition of silicon dioxide and potassium silicate was analyzed by X-ray fluoroscence spectrometry (XRF) and energy dipersive X-ray fluoroscence spectrometry (EDXRF, Minipal 4, PANalytical). Scanning electron microscopy (SEM) was used to observe the morphology of the product samples.

\section{RESULT AND DISCUSSION}

Fig. 3 shows the correlation of raw material ratio $\left(\mathrm{SiO}_{2} / \mathrm{K}_{2} \mathrm{O}\right)$ to the concentrations of silica and potassium prepared by $\mathrm{K}_{2} \mathrm{CO}_{3}$. The concentration of $\mathrm{SiO}_{2}$ and $\mathrm{K}_{2} \mathrm{O}$ on potassium silicate from geothermal sludge and pyrophylite followed the change of raw material ratio of $\mathrm{SiO}_{2} / \mathrm{K}_{2} \mathrm{O}$.

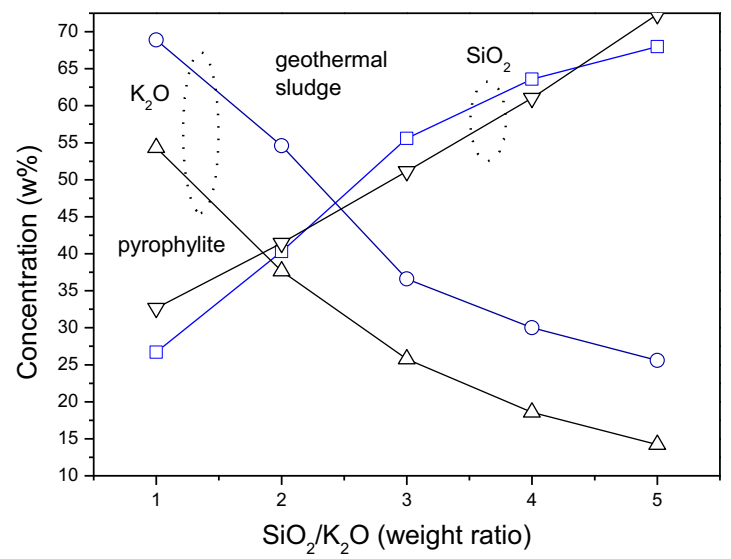

Figure 3. The correlation of raw materials ratio $\left(\mathrm{SiO}_{2} / \mathrm{K}_{2} \mathrm{O}\right)$ to the concentrations of silica and potassium in potassium silicate product prepared by $\mathrm{K}_{2} \mathrm{CO}_{3}$.

There was no significant difference for $\mathrm{SiO}_{2}$ concentration in the potassium silicate produced from these two types of raw materials, but there were significant differences in the concentration of potassium in potassium silicate product.
This shows that the potassium silicate produced from geothermal sludge and pyrophylite have different grade ratio in the same raw material ratio $\left(\mathrm{SiO}_{2} / \mathrm{K}_{2} \mathrm{O}\right)$.

Fig. 4 shows the effect of raw materials ratio on concentration of $\mathrm{K}_{2} \mathrm{O}$ in potassium silicate prepared by $\mathrm{KOH}$ and $\mathrm{K}_{2} \mathrm{CO}_{3}$. $\mathrm{KOH}$ provides the amount of $\mathrm{K}_{2} \mathrm{O}$ in potassium silicate which is slightly larger than $\mathrm{K}_{2} \mathrm{CO}_{3}$. The concentration of $\mathrm{K}_{2} \mathrm{O}$ in potassium silicate produced from pyrophylite was lower than that of geothermal sludge. In raw materials ratio $3: 1$ the concentration of $\mathrm{K}_{2} \mathrm{O}$ is $44.7 \%$ prepared by geothermal sludge and $\mathrm{KOH}$, and $24.8 \%$ prepared by pyrophyllite and $\mathrm{KOH}$. This indicated that the consumption of pottassium prepared by pyrophyllite larger than those prepared by geothermal sludge for the same expected molar ratio.

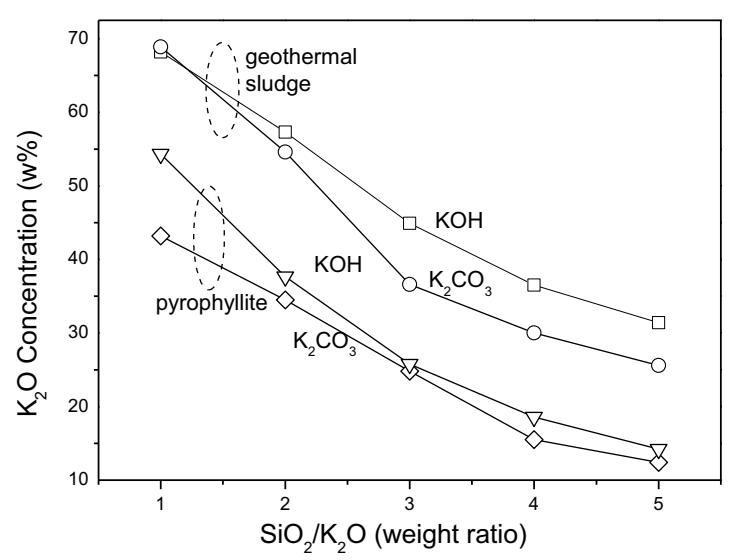

Figure 4. The effect of raw materials on the concentrations of potassium silicate solids.

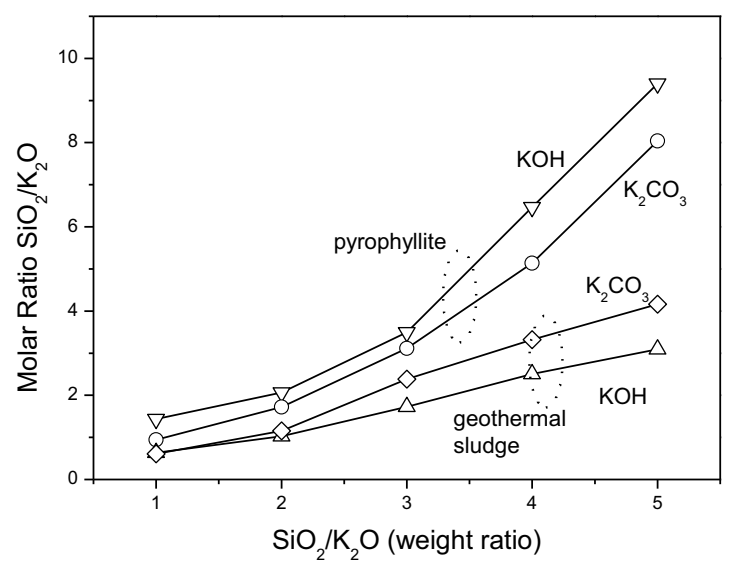

Figure 5. The effect of raw materials ratio on the molar ratio $\mathrm{SiO}_{2}: \mathrm{K}_{2} \mathrm{O}$

Fig. 5 shows the effect of raw materials ratio on the molar ratio $\mathrm{SiO}_{2}: \mathrm{K}_{2} \mathrm{O}$. Potassium silicate prepared by geothermal 
sludge and $\mathrm{KOH}$ has a molar ratio in the range of 0.6 - 3.1, which is less than the molar ratio of potassium silicate from pyrophyllite which is in the range of $1.4-9.4$. While $\mathrm{K}_{2} \mathrm{CO}_{3}$ produced potassium silicate with a molar ratio that is slightly larger than the $\mathrm{KOH}$ in the range of $0.6-4.1$. Amorphous silica from geothermal sludge facilitate the process of mixing and reaction.

Potassium silicate solid was prepared by geothermal sludge in accordance with the grade of fertilizer produced on the raw material weight ratio of $4: 1$ with a molar ratio to $2.5: 1$ for the use of $\mathrm{KOH}$, and the raw material weight ratio of $3: 1$ with a molar ratio of $2: 33: 1$ for the use of $\mathrm{K}_{2} \mathrm{CO}_{3}$.

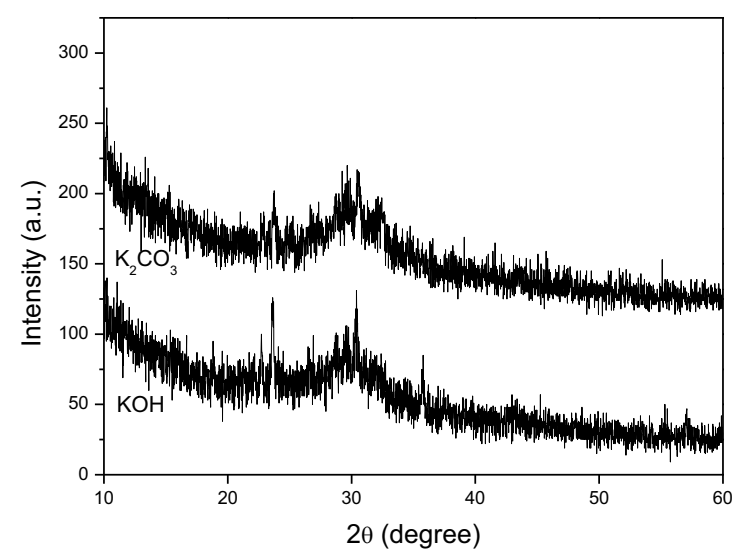

Figure 6. X-ray diffraction (XRD) patterns of potassium silicacate solids on the $1: 1$ weight ratio

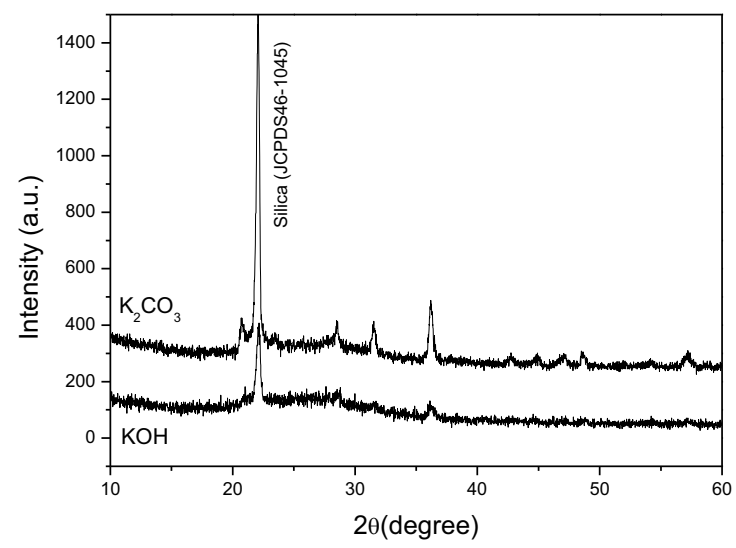

Figure 7. X-ray diffraction patterns of potassium silicacate solids prepared by the $4: 1$ weight ratio

Diffraction pattern of solid potassium silicate produced from geothermal sludge using $\mathrm{KOH}$ and $\mathrm{K}_{2} \mathrm{CO}_{3}$ in the weight ratio of $1: 1$ is shown in Fig. 6. Both samples showed amorphous nature but the little silica peaked at $22^{\circ}$ (JCPDS 46-1045). The contrast when the ratio increased to 4 $: 1$ as diffraction pattern shown in Fig. 7. The Silica intensity is very high (1300) at $22^{\circ}$ prepared by $\mathrm{K}_{2} \mathrm{CO}_{3}$ than prepared by $\mathrm{KOH}$ is 200 only. The potassium silicate from $\mathrm{KOH}$ samples appears largely amorphous with little traces of crystalline phase.

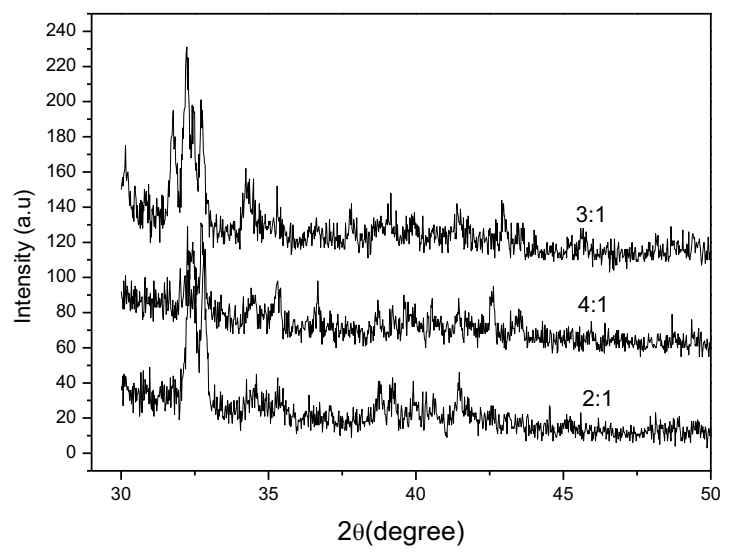

Figure 8. X-ray diffraction patterns of potassium silicacate solids prepared by pyrophyllite

Diffraction pattern of solid potassium silicate prepared by pyrophyllite using $\mathrm{K}_{2} \mathrm{CO}_{3}$ in the weight ratio of $2: 1,3: 1$, and 4:1 are shown in Fig. 8. Transformation of crystalline structure (Fig.2) into an amorphous (Fig 8.) occur during the fusion reaction between pyrophyllite (crystalline) with potassium underway. Amorphous structure on potassium silicate product can increase its solubility.

The yield of potassium silicate solid produced from geothermal sludge $(70-80 \%)$ is lower than those produced from pyrophyllite (91-97\%) prepared by KOH. In the other hand, the yield of potassium silicate from geothermal sludge prepared by $\mathrm{K}_{2} \mathrm{CO}_{3}(60-70 \%)$ is lower than prepared by $\mathrm{KOH}(70-80 \%)$.

The melting point of potassium carbonate is $891{ }^{\circ} \mathrm{C}$ and potassium hydroxide is $406{ }^{\circ} \mathrm{C}$, while the melting point of silica around 1600 to $1730{ }^{\circ} \mathrm{C}$. The difference between the melting point of silica and potassium lead to the melting point of a mixture of both to be different depending on the composition ratio of $\mathrm{SiO}_{2} / \mathrm{K}_{2} \mathrm{O}$. Fig. 9 shows the effect of raw material ratio $\left(\mathrm{SiO}_{2} / \mathrm{K}_{2} \mathrm{O}\right)$ on melting temperature. Because potassium hydroxide has the lowest melting point, the melting point of the mixture is in the range of $800^{\circ} \mathrm{C}$ to $1100{ }^{\circ} \mathrm{C}$. Based on the melting point of a mixture of geothermal silica and potassium in the molar ratio 3: 1 to 4: 1 the melting temperature up to $900{ }^{\circ} \mathrm{C}$ using $\mathrm{KOH}$ and up to $1100{ }^{\circ} \mathrm{C}$ using $\mathrm{K}_{2} \mathrm{CO}_{3}$. As for the mixture of pyrophyllite and potassium in the molar ratio 2: 1 reaches the melting temperature $1200{ }^{\circ} \mathrm{C}$ using $\mathrm{KOH}$ and $1350{ }^{\circ} \mathrm{C}$ using $\mathrm{K}_{2} \mathrm{CO}_{3}$. 


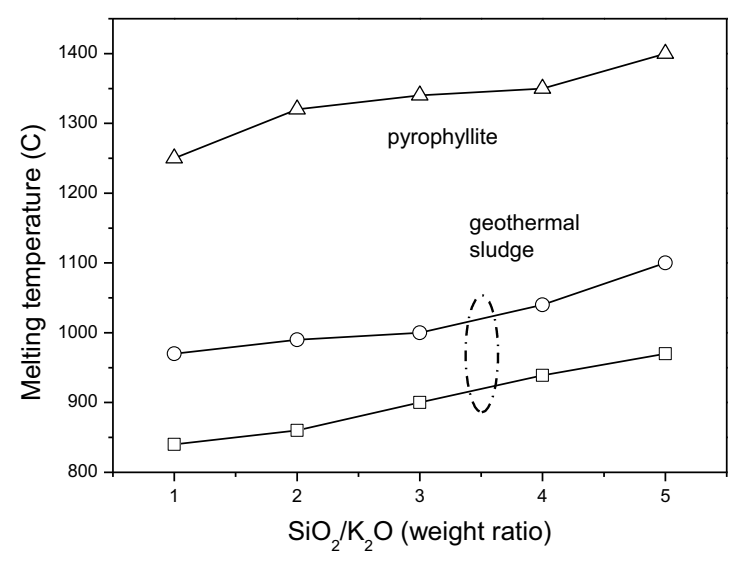

Figure 9. Effect of raw materials ratio $\mathrm{SiO}_{2} / \mathrm{K}_{2} \mathrm{O}$ on melting temperature

The SEM images shown in Fig. 10 confirm that the particles of potassium silicate prepared by $\mathrm{KOH}$ were smaller and more uniform than those prepared by $\mathrm{K}_{2} \mathrm{CO}_{3}$. The size distribution of the particles, as deduced from the SEM images, shows that particle size prepared by $\mathrm{KOH}$ is in the range of $62-145 \mathrm{~nm}$ and that prepared by $\mathrm{K}_{2} \mathrm{CO}_{3}$ is in the range of $40-220 \mathrm{~nm}$.

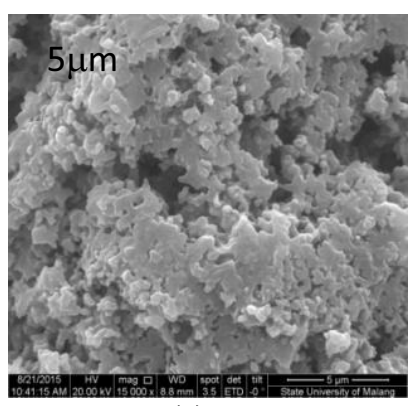

(a)

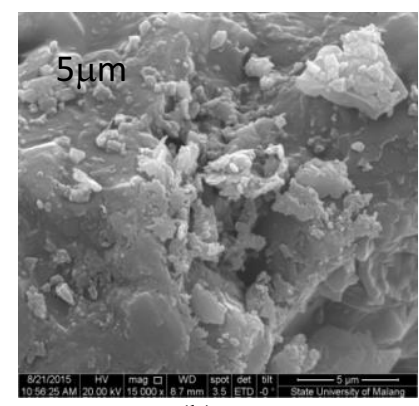

(b)
Figure 10. SEM images of potassium silicate solid from geothermal sludge prepared by (a) $\mathrm{KOH}$ and (b) $\mathrm{K}_{2} \mathrm{CO}_{3}$.

\section{CONCLUSION}

Characteristics of potassium silicate which is characterized by a molar ratio is influenced by the type of raw material and potassium salts used.

The amount of raw materials needed to get the appropriate molar ratio of potassium silicate fertilizer grade are different, as well as the temperature of the furnace.

Potassium silicate prepared by potassium hydroxide and amorphous silica from geothermal sludge showed in accordance with fertilizer at a low molar ratio (2.5:1), potassium requirement is quite small and a temperature of about $900{ }^{\circ} \mathrm{C}$. Meanwhile, the potassium silicate prepared from pyrophyllite produced a high molar ratio (1.4 - 9.4) and on a fusion temperature of about $1350{ }^{\circ} \mathrm{C}$, so that potassium needed large enough to meet the required molar ratio for the fertilizer grade.

The product of potassium silicate solid is amorphous with a little trace of crystalline.

\section{ACKNOWLEDGMENT}

The Authors are grateful to the Ministry of Research and Technology, Indonesia, for its financial support through Hibah Penelitian Unggulan. We also thank Mr. Ermawan of PT Geodipa Energi for providing the geothermal sludge and Mr Haryanto of PT Gunung Bale for providing pyrophyllite. Thank to Pradipta Utama and Dwi Agus Setiawan for assisting with the experiments.

\section{REFERENCES}

Gunnarsson, I.,Arnorsson, S., 2000, Amorphous silica solubility and the thermodynamic properties, Geochimica et Cosmochimica Acta, 64(13):2295-2307

Jayawardana, H,A,R,K., Weerahewa H.L.D., and. Saparamadu, M.D.J.S., 2014, Effect of Root or Foliar Application of Soluble Silicon on Plant Growth, Tropical Agricultural Research, Vol. 26 (1): $74-81$

Muljani, S., Setyawan, H., Sumada, K., 2011, Production of pure amorphous silica from geothermal sludge of Dieng, Indonesia, BISTECH-1 proceed ISSN 978-979-986231-0, D21:1-5.

Muljani, S., Setyawan, H., Wibawa, G., Altway, A., 2014, A facile method for the production of high-surface-area mesoporous silica gels from geothermal sludge, Advanced Powder Tech. 25(5): 1593-1599.

Nolla, A., Coelho, L., 2008, Potassium Silicate as Foliar Spray and Rice Blast Control, Journal of Plant Nutrition, 31: 231-237

Robert O. Fournier, R, O., Jack, J, R., 1977, The solubility of amorphous silica in water at high temperatures and high pressures, American Mineralogis, 62: 1052-1056.

Process for production of potassium silicate solutions by the addition of tempered quartz to hydrothermally reacted quartz and $\mathrm{KOH}$, US $5238668 \mathrm{~A}$

Production of silicates, US 2823098 A

Yao Y., Hamada E., Sato K., Takashi Akiyama T., Yoneyama T., 2014, Identification of the Major Constituents of Fused Potassium Silicate Fertilizer, ISIJ $\begin{array}{llll}\text { International, } & 54: & 4, & 990-993\end{array}$ 